cartilage and immediate chest stabilization [5]. In addition, he reported less postoperative pain, shorter hospital stays, lower complication rate, and decreased cost. Furthermore, he reported satisfactory cosmetic results with the less extensive repair, as well as a high rate of improvement in exertional symptoms compared with more extensive open surgical procedures. Recurrences are rare.

Responses to quality-of-life questionnaires in patients who had undergone minimally invasive repair of their pectus deformity supported a positive impact on psychosocial function [17].

\section{References}

1. Steinmann C., Krille S., Mueller A., Weber P., Reingruber B. Pectus excavatum and pectus carinatum patients suffer from lower quality of life and impaired body image: a control group comparison of psychological characteristics prior to surgical correction. Eur $J$ Cardiothorac Surg. 2011;40(5):1138-1145.

2. Mielke C. H., Winter R. B. Pectus carinatum successfully treated with bracing. A case report. Int Orthop. 1993;17(6):350-352.

3. Martinez-Ferro M., Fraire C., Bernard S. Dynamic compression system for the correction of pectus carinatum. Semin Pediatr Surg. 2008;17(3):194-200.

4. Obermeyer R. J., Goretsky M. J. Chest wall deformities in pediatric surgery. Surg Clin North Am. 2012;92(3):669684 , ix.

5. Fonkalsrud E.W. Surgical correction of pectus carinatum: lessons learned from 260 patients. J Pediatr Surg. 2008;43(7):1235-1243.

6. Heithaus J. L., Davenport S., Twyman K. A., Torti E. E., Batanian J. R. An intragenic deletion of the gene MNAT1 in a family with pectus deformities. Am J Med Genet $A$. 2014;164A(5):1293-1297.

7. Calloway E. H., Chhotani A. N., Lee Y. Z., Phillips J. D. Three-dimensional computed tomography for evaluation and management of children with complex chest wall anomalies: useful information or just pretty pictures? $J$ Pediatr Surg. 2011;46(4):640-647.

8. Castile R. G., Staats B. A., Westbrook P. R. Symptomatic pectus deformities of the chest. Am Rev Respir Dis. 1982; 126(3):564-658.
Conclutions. Symptoms that were reported for these patients included dyspnea, exertional tachypnea, and reduced endurance as well as low self-esteem making the therapy important for the personality development of these children. Over time, the trend towards less surgical techniques has resulted in low morbidity, mild pain, short hospital stay and very good physiologic and cosmetic results. Therefore, according to our results we currently offer this approach as a first-line treatment for pectus carinatum.

9. Frey A. S., Garcia V. F., Brown R. L. et al. Nonoperative management of pectus carinatum. I Pediatr Surg. 2006;41(1):40-45.

10. Lee R. T., Moorman S., Schneider M., Sigalet D. L. Bracing is an effective therapy for pectus carinatum: interim results. J Pediatr Surg. 2013;48(1):184-190.

11. Wong K. E., Gorton G. E. 3rd, Tashjian D. B., Tirabassi M. V., Moriarty K. P. Evaluation of the treatment of pectus carinatum with compressive orthotic bracing using three dimensional body scans. J Pediatr Surg. 2014;49 (6):924-927.

12. Kobayashi S., Yoza S., Komuro Y., Sakai Y., Ohmori K. Correction of pectus excavatum and pectus carinatum assisted by the endoscope. Plast Reconstr Surg. 1997;99(4):1037-1045

13. de Matos A. C., Bernardo J. E., Fernandes L. E., Antunes M. J. Surgery of chest wall deformities. Eur $J$ Cardiothorac Surg. 1997;12(3):345-350.

14. Shamberger R. C., Welch K. J. Surgical correction of pectus carinatum. J Pediatr Surg. 1987;22(1):48-53.

15. Del Frari B., Schwabegger A. H. Ten-year experience with the muscle split technique, bioabsorbable plates, and postoperative bracing for correction of pectus carinatum: the Innsbruck protocol. J Thorac Cardiovasc Surg. 2011;141(6):1403-1409.

16. Cohee A. S., Lin J. R., Frantz F. W., Kelly R. E. Staged management of pectus carinatum. I Pediatr Surg. 2013;48(2):315-320.

17. Cano I., Anton-Pacheco J. L., Garcia A., Rothenberg S. Video-assisted thoracoscopic lobectomy in infants. Eur J Cardiothorac Surg. 2006;29(6):997-1000.

About author:

Zachariou Zacharias, MD, PhD, Professor, Pediatric Surgeon, Medical School of University of Cyprus;

tel.: +35799273371; e-mail: zachariou.a.zacharias@ucy.ac.cy

(C) Group of authors, 2016

UDC 616.348-002-053.2

DOI - http://dx.doi.org/10.14300/mnnc.2016.11023

ISSN - 2073-8137

\title{
FAST TRACK IN THE TREATMENT OF NEWBORNS WITH NECROTIZING ENTEROCOLITES
}

Minaev S. V. ${ }^{1}$, Obedin A. N. ${ }^{1}$, Kachanov A. V. ${ }^{1}$, Annenkov M. V. ${ }^{2}$, Tovkan E. A.2', Gerasimenko'I. N.'

1 Stavropol State Medical University, Russian Federation

2 Regional Children's Clinical Hospital, Stavropol, Russian Federation

\section{УСКОРЕННАЯ РЕАБИАИТАЦИЯ В АЕЧЕНИИ НОВОРОЖАЕННЫХ С НЕКРОТИЧЕСКИМ ЭНТЕРОКОАИТОМ}

\author{
С. В. Минаев ${ }^{1}$, А. Н. Обелин ${ }^{1}$, А. В. Качанов ${ }^{1}$, М. В. Анненков ${ }^{2}$ \\ Е. А. Товкань ${ }^{2}$, И. Н. Герасименко
}

1 Ставропольский госуаарственный меАицинский университет, Российская ФеАерация 2 Краевая Аетская кАиническая больница, Ставрополь, Российская Фелерация

In the article consider the actual problem of fast track in newborns with NEC. Patients were divided into two groups matched for gestational age, weight and sex of patients. The Group1 consisted of 18 infants with NEC stage 2 to 3 , in which the complex treatment was provided using presacral blockade with ropivacaine. The Group 2 was 
represented by 17 patients with NEC stage 2-3 undergoing standard treatment program. After 16 hours from the start of treatment in the Group 1 with respect to the Group 2 there was a significant decrease in the level of pain on a CHEOPS scale $(6.0 \pm 0.5$ points and $9.5 \pm 0.3$ points, respectively, $p=0.001)$. Was shown substantial and significant reduction in the dose of fentanyl in the case of surgical intervention $(62 \pm 2.5 \mathrm{mcg}$ and $120 \pm 3.2 \mathrm{mcg}$, respectively, $p=0.002)$, respectively. Staying at mechanical ventilation after surgery was also reduced ( $1.5 \pm 0.8$ days and $3.4 \pm 1.1$ days, respectively). Significantly lower level of systemic and local inflectional complications was found in the Group1. Thus, holding presacral blockades with ropivacaine is an effective method of accelerating the recovery of infants with NEC, bringing the methodology of conducting to the fast track technology.

Key words: necrotizing enterocolitis, CHEOPS scale, treatment, fast track, newborns

Исследование посвящено актуальной проблеме ранней реабилитации новорожденных с некротическим энтероколитом (НЭК). Пациенты были распределены на две группы, сопоставимые по гестационному возрасту, весу и полу. Первую группу составили 18 новорожденных с НЭК 2-3 стадии, у которых в комплексе лечения проводили пресакральные блокады с ропивакаином. Вторая группа была представлена 17 пациентами с НЭК 2-3 стадии, которым проводили стандартную программу лечения. Через 16 часов от начала лечения в первой группе по отношению ко второй группе отмечалось достоверное снижение уровня болевого ощущения по шкале CHEOPS (6,0 0,5 балла и 9,5 $\pm 0,3$ балла соответственно, $p=0,001)$. Происходило существенное и достоверное сокращение дозы вводимого фентанила в случае проведения оперативного вмешательства

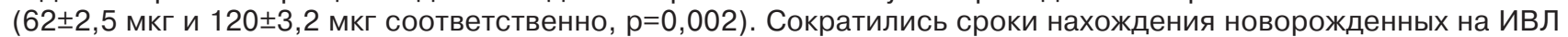

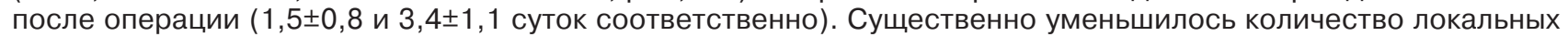
и системных осложнений. Таким образом, включение в комплекс терапии регионарных методов анестезии, таких как пресакральные блокады ропивакаином, позволяет существенно ускорить послеоперационную реабилитацию новорожденных с НЭК.

Ключевые слова: некротический энтероколит, оценка боли, лечение, технология ускоренной реабилитации, новорожденные

T

reatment of necrotizing enterocolitis (NEC) in newborns remains an urgent problem in modern pediatric surgery and intensive care. The main reason is a large amount of septic complications and high mortality in this group of patients [8, 10]. In this connection, it is important to search for technologies that allow minimize quantity and severity mentioned above complications [1, 4, $15,17]$. One way of solving this problem is use of modern technologies in perioperative care "fast-track" technology [5, 9, 11]. We believe that the rapid rehabilitation technologies for patients with NEC can greatly reduce the number of complications and thus improve survival rate in newborns with intestinal pathology indicated above.

The aim of our study was to investigate the efficiency of sacral plexus anesthesia with ropivacaine to accelerate the rehabilitation of newborns NEC.

Material and Methods. During the period from 2012 to 2016 years we have treated 35 newborns with NEC. The boys were 23, girls - 12. Gestational age was $33 \pm 0.8$ weeks. Birth' body mass was equal $1560.3 \pm 83.53$ grams. Newborns were divided into 2 groups. In the Group 1 of 18 children with NEC ordinary way of surgical and intensive care was combined with specific technique of regional anesthesia - presacral anesthesia with ropivacain. In the Group 2 was 17 infants with NEC receiving only conventional methods of perioperative care. Patients in both groups were matched for age, weight and gender. In addition to the conventional indicators we checked the pain score by CHEOPS scale at admission, and at 2, 4, 8 and 16 hours after onset of treatment, including also presacral anesthesia. Patients were evaluated at possible weaning from respiratory support following the surgery and interventions. We compared the dose of fentanyl administered during surgery in groups, as well as the duration of mechanical ventilation. Study endpoints were: mortality and the number of intra- and extra-abdominal complications (enteroplegia, perforation of a hollow organ, the development of diffuse peritonitis, pulmonary-pleural and septic complications). The control group consisted of 20 healthy newborns without evidences of NEC.

Analysis of the significance of differences in the groups was carried out in variational statistics methods throw the licensed computer program «Statistica 6.0" (StatSoft, USA). Data analysis included standard methods of descriptive and analytical statistics. A statistically significant difference in the groups was assessed by Mann - Whitney test, considering significant differences in the groups at $p<0.05$.

Results and Discussion. In newborns with NEC level of pain was significantly higher than in neonates of the control group. The estimate for the CHEOPS scale between the groups did not differ significantly and was $11.7 \pm 0.03$ points and $12.0 \pm 0.01$ points, respectively. After 2 hours Group 1 indicated statistically significant differences compared to the original data in the severity of pain. These differences persisted for a long time, and were characterized by a strong tendency of reducing the severity of pain and the approximation of the value determined by CHEOPS scale to that of the control group up to 16 hour of treatment which was initiated (Figure).

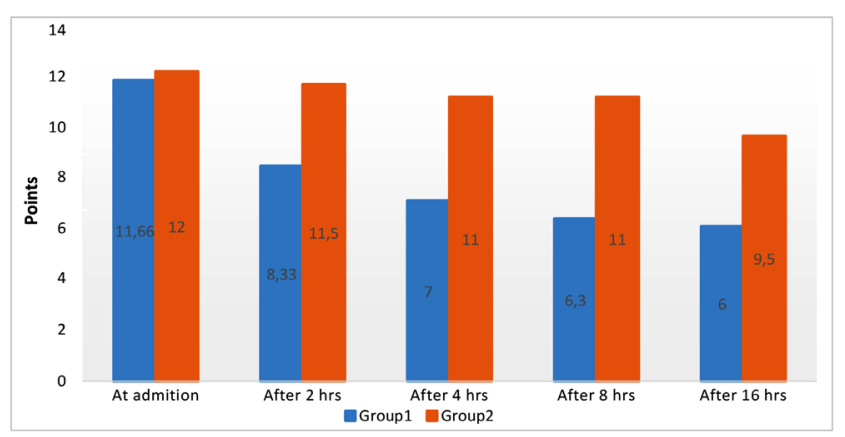

Fig. Dynamics CHEOPS scale indicators for the observed groups (in points) 
A different picture was observed in Group 2 Statistically significant differences in comparison with the original data were recorded only during the first 2 hours after starting the therapy. After 4 and 8 hours statistically significant differences from baseline were observed. After 16 hours from the beginning of the treatment, the further ongoing analgesic therapy Group 2 level of pain by CHEOPS scale was significantly higher than in the same period of observation in Group $1(9.5 \pm 0.28$ points and $6.0 \pm 0.5$ points $(p=0.001)$, respectively).

Dynamics of pain in newborns clearly showed that in Group1 duration and severity of analgesia was significantly higher, than in the Group 2. It proved to be significant that the reduction in pain score by CHEOPS scale approached to normal values in 16 hours after initiation of NEC therapy.

It should be noted that the conduction treatment provides substantial and significant $(p<0.05)$ reduction in the dose of fentanyl in the case of surgery, in Group 1 compared to Group $2(62 \pm 2.5 \mathrm{mcg}$ and $120 \pm 3.2 \mathrm{mcg}$, respectively).

Thus it was one of the main reasons for shortening of the period of time when infants were exposed to mechanical ventilation after surgery. In Group 1, the average time of weaning from ventilator was $1.5 \pm 0.8$ days approximately, and in Group $2-3.4 \pm 1.1$ days. It was not surprising that the number of pulmonary complications and duration of enteroplegia in Group 1 was significantly lower than in the Group2. Similarly, the overall incidence of infectious complications was lower in the Group 1 (Table).

Comparative characteristics of the study groups

Table after surgery

\begin{tabular}{|c|c|c|c|c|}
\hline Group & $\begin{array}{c}\text { Ven- } \\
\text { tilator } \\
\text { (days), } \\
M \pm m\end{array}$ & $\begin{array}{c}\text { The } \\
\text { dose } \\
\text { of } \\
\text { fentanyl } \\
(\mathrm{mcg}), \\
\mathrm{M} \pm \mathrm{m}\end{array}$ & $\begin{array}{c}\text { The } \\
\text { duration } \\
\text { of intesti- } \\
\text { nal paresis } \\
\text { (days), } \\
\mathrm{M} \pm \mathrm{m}\end{array}$ & $\begin{array}{c}\text { The total } \\
\text { number } \\
\text { of compli- } \\
\text { cations, } \\
\mathrm{n}(\%)\end{array}$ \\
\hline $\begin{array}{c}\text { Group 1 } \\
(\mathrm{n}=18)\end{array}$ & $1.5 \pm 0.8$ & $62 \pm 2.5^{*}$ & $2.4 \pm 0.5^{*}$ & $2(13.3 \%)^{*}$ \\
\hline $\begin{array}{c}\text { Group 2 } \\
(\mathrm{n}=17)\end{array}$ & $3.4 \pm 1.1$ & $120 \pm 3.2$ & $4.5 \pm 0.7$ & $5(38.4 \%)$ \\
\hline
\end{tabular}

${ }^{*} p<0.05$ compared with the group number 2 .

\section{References}

1. Bairov V. G., Karavayeva S. A., Amidhonova S. A., Suchocka A. A., Hidirov A. F. Comparative characteristics of anastomoses in atresia of small and large intestine in the newborn. Pediatric Surgery (Russia). 2013;(5):2023.

2. Karpova I. J., Parshikov V. V., Batanov G. B. Experience of surgical treatment of infants with necrotizing enterocolitis. Vestnik khirurgii imeni I. I. Grekova. 2012;171(2):5860.

3. Parshikov V. V., Ploharsky N. A., Karpova I. Y., Rites V. P. Experience with laparostomy in the treatment of necrotizing enterocolitis in stage before perforation. Pediatric Surgery(Russia). 2011;(2):50-51.

4. Knorring G. Y., Sternin Y. I., Minaev S. V., Novozhilov A. A. Intensification of antibiotic therapy for chronic inflammatory diseases. Voen Med Zh. 2008;329(10):35-40.

5. Hall N. J., Eaton S., Pierro A. Necrotizing enterocolitis: Prevention, treatment, and outcome. J Pediatr Surg. 2013;48(12):2359-2367. doi:10.1016/j.jpedsurg.2013.08.006

6. Papillon S., Castle S. L., Gayer C. P., Ford H. R. Necrotizing Enterocolitis Contemporary Management and Outcomes. Adv Pediatr. 2013;60:263-279. doi:10.1016/j. yapd.2013.04.011
In the course of the study [7] there was observed higher effectiveness of analgesia with regional methods at the NEC in newborns. When carrying out the standard scheme of management of patients significant differences from baseline values at high CHEOPS scale evaluations are stored only for a few hours. Starting from the 4th hour therapy, statistically significant differences compared with the original data were not found. At the same time, the differences between the groups became statistically significant. Consequently, the emerging trend of changes in indicators remained on the same level. In the group of infants with NEC, where the ropivacaine block of presacral plexus of combined anesthesia was used, the degree of severity of pain on a scale CHEOPS was significantly lower than in the other group. These differences continued to be the same up to the 16 hours from the beginning of intensive care.

The main role in the development of fast-track protocol is that it minimizes surgical intervention and changes the approach to anesthetic management by reducing the administration of opiates and early weaning the patient from the ventilator [16]. Given the evidence of the negative impact of opiates on the developing infant brain fast track technology has a great future in pediatrics [2, 12]. From the perspective of the pathogenesis of neonatal NEC is very interesting work confirming the relationship between the degree of pain and the severity of vasospasm internal organs, including intestine [6, 14]. Therefore, we should understand that effective pain management can help reduce the number of complications and mortality level in infants who developed NEC $[3,13]$.

In infants with NEC from Group1 showed rare cases of complications (local and systemic), which required surgical intervention in the first 3 days from the time of establishing NEC diagnosis. In addition, reduction in mortality in patients, who had received regional presacral anesthesia with ropivacain was observed. Thus, the technology of accelerated rehabilitation of infants with NEC proves to be effective in reducing the number of complications and moreover, it can reduce the level of mortality. To clearly prove that fact, we need to provide further studies in this field.

Conclusions. Thus, the use of ropivacaine blockades is safe and effective method which can improve analgesia in newborn infants with NEC. This significantly reduces the opioid's dosage in the perioperative period and shortens time spent on mechanical ventilation in the postoperative period, bringing the management of patients to fast-track technology.

7. Obedin A. N., Kachanov A. V., Annenkov M. V., Tovkan E. A., Kiriyenko O. S. Necrotizing enterocolitis in newborns. Do we all do to save their patients? Meditsinskii Vestnik Severnogo Kavkaza. - Medical News of North Caucasus. 2015;10(2):140-143; doi:10.14300/ mnnc.2015.10026

8. Tsap N. A., Kuznetsov N. N., Novoselova O. V., Abolina T. B. Surgical treatment and prognosis of the postoperative period in infants with necrotizing enterocolitis. Pediatric Surgery (Russia). 2004;(2):13-15.

9. Minaev S. V. Isaeva A. V. Tovkan E. A., Zagumennaya I. Y., Kachanov A. V., Filipeva N. V. Ultrasound diagnosis in infants with necrotizing enterocolitis. Doctor.Ru. 2014;3(91):31-33.

10. Karavaeva S. A. Diagnosis and clinical features of necrotizing enterocolitis in children. Vestnik khirurgii imeni I. I. Grekova. 2008;161(4):41-44.

11. Karavaeva S. A., Popova E. B Suchocka A , Levadny Y Neckrotising enterocolitis - diagnosis and treatment: a tutorial. - St. Petersburg, 2015;42.

12. Raval M. V., Hall N. J., Pierro A., Moss R. L. Evidence-based prevention and surgical treatment of necrotizing enterocolitis-a review of randomized co $n$ trolled trials. Semin. Pediatr. Surg. 2013;3:117-121. 
13. Amer M. D., Hedlund E., Rochester J., Caplan M. S. Platelet-activating factor concentration in the stool of human newborns: effects of enteral feeding and neonatal necrotizing. Biol. Neonate. 2004;85(3):159-166.

14. Eaton S., Rees C. M., Hall N. J. Current research in necrotizing enterocolitis. Early Hum Dev. 2016;97:33-39. doi:10.1016/j.earlhumdev.2016.01.013

15. Minaev S. V., Isaeva A. V., Tovkan E. A., Gudiev Ch. G., Timofeev S. I. et al. The prognostic value of bactericidal/ permeability-increasing protein in infants with congenital pathology of the gastrointestinal tract. Meditsinskii Vestnik Severnogo Kavkaza. - Medical News of North Caucasus. 2014;9(2):116-119. doi:10.14300/ mnnc.2014.09032

16. Siggers R. H., Siggers J., Thymann T., Boye M., Sangild P. T. Nutritional modulation of the gut microbiota and immune system in preterm neonates susceptible to necrotizing enterocolitis. J Nutr Biochem. 2011;22(6):511521. doi: 10.1016/j.jnutbio.2010.08.002

17. Watkins D.J., Besner G.E. The role of the intestinal microcirculation in necrotizing enterocolitis. Semin. Pediatr. Surg. 2013;22:83-87. doi: 10.1007/s00383015-3697-9

\title{
About authors:
}

Minaev Sergey, MD, PhD, Professor, Head of Department of Pediatric Surgery with the course of additional vocational training; tel: +79624507653; e-mail: sminaev@yandex.ru

Obedin Alexander, MD, PhD, professor's assistant, Head of Department of Anesthesiology and Intensive Care;

tel .: +79034169771; e-mail: volander@mail.ru

Kachanov Alexander, post-graduate student of the Department of Pediatric Surgery with the course of additional vocational training; e-mail: +79283174974@ mail.ru

Annenkov Mikhail, Head of Department of the intensive care; e-mail: annenkovmv@gmail.com

Tovkan Elena, MD, Head of Department of newborns and premature babies;

e-mail: el.tovkan@yandex.ru

Gerasimenko Igor, MD, Assistant of the Department of Pediatric Surgery with the course of additional vocational training;

e-mail: igor9551@yandex.ru

(C) Group of autors, 2016

UDC 616.69-008.1:616.379-008.64:612.616.31

DOI - http://dx.doi.org/10.14300/mnnc.2016.11024

ISSN 2073-8137

\section{COULD ERECTILE DYSFUNCTION IN TYPE 2 DIABETES CHANGE THE PRESUMPTION OF NORMATIVE TOTAL BLOOD SERUM TESTOSTERONE?}

Kogan M. I., Belousov I. I., Khripun I. A., Vorobyev S. V., Ibishev Kh. S., Dzantieva E. O., Chernyi A. A.

Rostov State Medical University, Russian Federation

\section{МОЖЕТ АИ ЭРЕКТИАЬНАЯ АИСФУНКЦИЯ У БОАЬНЫХ С САХАРНЫМ АИАБЕТОМ 2 ТИПА ИЗМЕНИТЬ ПРЕАСТАВАЕНИЕ О НОРМАТИВНОМ УРОВНЕ ОБЩЕГО ТЕСТОСТЕРОНА СЫВОРОТКИ КРОВИ?}

\author{
М. И. Коган, И. И. Белоусов, И. А. Хрипун, С. В. Воробьев, Х. С. Ибишев, \\ Е. О. Азантиева, А. А. Черный
}

\section{Ростовский госуАарственный меАицинский университет, Российская ФеАерация}

According to research data, the ED is detected in 50-75\% of men with T2DM. During the last decade, the problem of ED in the presence of late onset hypogonadism has been actively studied. There is convincing proof that total serum testosterone $(T)$ deficit influences the development and severity of ED, including in T2DM. The principal aim of the current study was to evaluate ED in males with T2DM at low and middle-to-high normative levels of T.

We have performed a prospective randomized simple comparative study of 86 male patients with T2DM and T level higher than $12.0 \mathrm{nmol} / \mathrm{l}$. The patients were divided into two groups, with low normative level of T and with middle - to high normative T levels. Standard methods of objective evaluation did not permit discrimination in the T2DM compensation. At the same time the diseases based on vascular pathology, dyslipidemia and vascular endothelial dysfunctions were more frequently found in patients with middle-to-high normal T levels. In the two groups of patients the severity of androgen deficiency symptoms was found out to be unequal. The IIEF- 5 questionnaire showed significant difference in frequency and severity of ED and significant relation to T levels. Males with T2DM and normotestosteronemia at $12-15 \mathrm{mmol} / \mathrm{I}$ are at higher risks of dyslipidemia, endothelium disorders and progress of T2DM as compared to males with blood T of $>15 \mathrm{mmol} / \mathrm{l}$.

Key words: erectile dysfunction, testosterone, type 2 diabetes mellitus

По данным исследователей, ЭД выявляется у 50-75 \% мужчин с СД 2 типа. Получены убедительные доказательства о влиянии дефицита Тобщ на развитие и тяжесть эректильных нарушений, в том числе и при СД 2 типа. Основной целью настоящего исследования явилась оценка нарушений эректильной функции у мужчин, 